\title{
On the way of the new strategies aimed to improve the efficacy of PD-1/PD-L1 immune checkpoint blocking mAbs in small cell lung cancer
}

\author{
Pierpaolo Correale $^{1} \wedge$, Rocco Giannicola ${ }^{1}$, Rita Emilena Saladino ${ }^{2}$, Valerio Nardone ${ }^{3} \wedge$, Luigi Pirtoli ${ }^{4} \wedge$, \\ Pierfrancesco Tassone $^{5 \wedge}$, Amalia Luce ${ }^{6 \wedge}$, Salvatore Cappabianca ${ }^{6} \wedge$, Marianna Scrima ${ }^{7} \wedge$, \\ Pierosandro Tagliaferri ${ }^{8} \wedge$, Michele Caraglia ${ }^{6,7} \wedge$
}

${ }^{1}$ Medical Oncology Unit, Grand Metropolitan Hospital "Bianchi-Melacrino-Morelli”, Reggio Calabria, Italy; ${ }^{2}$ Tissue Typing Unit, Grand Metropolitan Hospital "Bianchi-Melacrino-Morelli”, Reggio Calabria, Italy; ${ }^{3}$ Radiotherapy Unit, "Ospedale del Mare”, ASL Napoli 1, Naples, Italy; ${ }^{4}$ Sbarro Institute for Cancer Research and Molecular Medicine and Center of Biotechnology, Department of Biology, College of Science and Technology, Temple University, Philadelphia, PA, USA; ${ }^{5}$ Department of Experimental and Clinical Medicine, Magna Graecia University, Catanzaro, Italy; 'Department of Precision Medicine, University of Campania "L. Vanvitelli”, Naples, Italy; ${ }^{7}$ Biogem Scarl, Institute of Genetic Research, Laboratory of Precision and Molecular Oncology, Ariano Irpino, Avellino, Italy; ${ }^{8}$ Medical Oncology Unit, AUO "MaterDomini”, "Magna Graecia" University, Catanzaro, Italy

Correspondence to: Michele Caraglia, MD, PhD. Department of Precision Medicine, University of Campania "L. Vanvitelli", Via L. De Crecchio, 7, 80138 Naples, Italy \& Biogem Scarl, Institute of Genetic Research, Laboratory of Precision and Molecular Oncology, Contrada Camporeale, 83031 Ariano Irpino, Avellino, Italy. Email: michele.caraglia@unicampania.it; Pierpaolo Correale, MD, PhD. Medical Oncology Unit, Grand Metropolitan Hospital "Bianchi-Melacrino-Morelli”, Via Melacrino 1, 89124 Reggio Calabria, Italy. Email: correalep@yahoo.it.

Comment on: Sun Y, Zhai C, Chen X, et al. Characterization of PD-L1 protein expression and CD8+ tumor-infiltrating lymphocyte density, and their associations with clinical outcome in small-cell lung cancer. Transl Lung Cancer Res 2019;8:748-59.

Submitted Apr 06, 2020. Accepted for publication Apr 21, 2020.

doi: $10.21037 /$ tlcr-20-536

View this article at: http://dx.doi.org/10.21037/tlcr-20-536

\section{Introduction}

Small cell lung cancer (SCLC) is the third most frequent lung cancer histology and accounts for $10-15 \%$ of them. SCLC patients have a poor prognosis due a very high natural aggressiveness of the disease, early widespread metastasis with central nervous system (CNS) involvement and occurrence of para-neoplastic syndromes (1). Tumor tissue is usually represented by crowded nests and cords of highly proliferating small cells presenting undifferentiated neuroendocrine tracts that in turn could explain their extraordinary ability to spread in the CNS and develop multidrug resistance. The only approved treatment for these patients has been represented by platinum derivatives (cisplatin and carboplatin) in combination with intravenous etoposide or irinotecan $+/$ - radiation therapy. The majority of these patients present a high response rate associated with a median overall survival (OS) of 25-30 months in those diagnosed with an early stage (I-III) disease (15-20\% of the cases) and less than 10 months in those unfit for chemotherapy and/or diagnosed in advanced stage disease ( $80-85 \%$ of the cases). On the overall SCLC patients present a 5 -year survival rate of $6-10 \%$

^ ORCID: Pierpaolo Correale, 0000-0003-2154-6734; Valerio Nardone, 0000-0002-7347-0965; Luigi Pirtoli, 0000-0003-3037-4209; Pierfrancesco Tassone, 0000-0002-8298-6787; Amalia Luce, 0000-0003-0372-6870; Salvatore Cappabianca, 0000-0002-5417-2268; Marianna Scrima, 0000-0003-4636-7695; Pierosandro Tagliaferri, 0000-0002-1535-2477; Michele Caraglia, 0000-0003-2408-6091. 
with virtually no significant changes in the last 30 years despite of the enormous number of drugs that have been investigated in these patients setting $(1,2)$. In the last few years, cancer immunotherapy has known an enthusiastic breakthrough because of the successful clinical development of monoclonal antibodies (mAbs) against programmed cell death receptor-1 (PD-1) (nivolumab and pembrolizumab) and PD-1 ligand-1 (PD-L1) (atezolizumab, avelumab and durvalumab) able to break immune tolerance related to PD-1/PD-L1 peripheral immune checkpoint (ICP) showing significant antitumor activity in a number of different malignant diseases including NSCLC, malignant melanoma, head and neck, urological and kidney cancer (3). Immune checkpoint blockade resulted very successful in the treatment of NSCLC patients where these mAbs alone or in combination with chemotherapy were associated to a significant benefit and outstanding response rate, progression-free survival (PFS) and overall survival (OS) (4). In light of this enthusiasm the possible use of immune checkpoint blockade with anti-PD-1/PD-L1 mAbs alone has been also tested in pretreated SCLC patients in several clinical trials showing a response rate lower than $20 \%$ and very limited efficacy in pretreated patients not bearing a high tumor mutation burden (5). More proficient results were achieved when central and peripheral immune checkpoint blockade combination strategy with antiCTLA-4 and anti-PD-1 was adopted and associated to a 2 -year OS rate greater than $30 \%$. Unfortunately, also this strategy did not achieve sufficient scientific evidence to be approved as a standard treatment for SCLC patients (6). More recently, a randomized phase III trial (IMpower133) demonstrated a markedly prolonged PFS and OS when atezolizumab an anti-PD-L1 mAb was used in combination with carboplatin and etoposide. This regimen showed superiority over placebo plus etoposide and carboplatin (7) and was finally approved for the front-line treatment of these patients even though the response in term of either PFS and OS were very far from the outstanding results achieved in squamous and non-squamous NSCLC patients. In this context, the identification of potential strategies based on the use of immune checkpoint inhibitors alone or combinations in the treatment of SCLC patients remains challenging and requires further studies aimed to identify potential biomarker predictive of response and translational models to improve its efficacy. The starting point for these kinds of studies should be based on the knowledge of the mechanism of action of the different known immune checkpoints that are physiological instruments able to attenuate dangerous immunologic overreactions to pathogens and self-antigens.

\section{Immune response and immune checkpoint inhibitors}

Central immune checkpoints act in the lymph nodes and other lymphoid organs where $\mathrm{T}$ cell proliferation happens upon $\mathrm{T}$ cell receptor (TCR) mediated interaction with peptide antigens bound to class I/II human leukocyte antigens (HLA), antigen presenting cells (APC) and a dynamic equilibrium between stimulatory (co-accessory/ costimulatory molecules, such as those derived by early CD28 interaction with B7.1/B7.2) and inhibitory signals [regulatory T cells (Tregs) and central immune-checkpoints, such as those derived by late CTLA-4 interaction with B7.1/B7.2]. Once activated the antigen specific CD $8^{+}$ $\mathrm{T}$ cell precursors migrate in the specific sites where the immunological attack takes place (viral infection or tumor transformation, etc.) and there specifically recognize and kill the target cells expressing on their surface the target epitopes bound to complementary class I HLA molecules. These 8-10 mere epitope peptides are the product of cytoplasmic proteolysis of protein antigens and their binding to HLA molecules is related to specific anchorage amino acid consensus motifs which make them HLA haplotype and allele specific. It is speculative that tumor expressing the same antigens may produce a completely different immune response if the bearing patients present dissimilar class I and /II HLA alleles. On the long term, however, these over-reactive cytotoxic $\mathrm{T}$ lymphocytes (CTLs) might become dangerous and therefore need to be attenuated throughout the interaction of specific inhibitors with their ligands (i.e., PD-1 with its ligand PDL1 and 2 that are expressed on specific immune-suppressive inflammatory cells and sometime by tumor cells) or other immune-suppressive cell lineages such as Tregs and myeloid derivative suppressor cells (MDSCs) (8). In this context PD-1/PD-L1 immune checkpoint blocking mAbs are unable to exert a direct antitumor effect alone, rather their use induces the reactivation of preexisting tumor infiltrating CTLs inactivated throughout the PD-1 pathway (8). In order to have an efficient antitumor activity mAbs against PD-1 and PD-L1 in cancer patients need the presence of an adequate number of tumor-reactive CTL able to set off an efficient tumor rejection. On the other perspective, it is also necessary that tumor cells produce a sufficient amount of immunogenic tumor-associated antigens (TAAs) and tumor- 
specific antigens (TSAs) able to ignite a proficient tumor specific immune response. The presence of these antigens is strictly related to the processes of carcinogenesis which may be very different for each different tumor type (9).

\section{Immunotherapy in small cell lung cancer}

In the last thirty years, the immunological treatment of SCLC patients has always been very challenging due to clinical as well as immune-biological issues. In the first place, it is a fast-growing malignant disease that rapidly produces severe detrimental consequences on patients' clinical conditions and that requires immediate action to reduce as fast as possible either tumor burden and or mediastinal congestion events that presently need the prompt use of chemotherapy with or without radiation therapy. Additionally, SCLC is associated with smoking habit and often these patients present severe co-morbidities including chronic inflammatory bronchopulmonary diseases, infections and cardiovascular diseases. For what concerns the other immune-biological issues, there is clear evidence that tumor samples derived from SCLC patients commonly present a high mutational burden and a number of TAAs and TSAs potentially targetable in protocols of immunotherapy. However, this potential advantage is lost considering that tumor tissue derived from SCLC patients presents a low expression of HLA molecules, a low rate of CTL infiltration and a high expression of immune-suppressive MSDCs and Tregs whose presence is strictly correlated with a chronic state of systemic inflammation (10).
Additionally, due to their rapid growth this tumor develops multiple poorly vascularized areas with consequent hypoxia and adenosine release that in turn produce a powerful immune-suppressive effect (11). All together these issues may explain the contrasting results achieved for what concerns the immune checkpoint blockade in SCLC patients. It should also be taken in consideration that there is a no univocal consensus on the expression rate of PDL1 in SCLC as a number of study reports contrasting results and at the present it cannot be considered as a reliable biomarker of response to PD-1/PD-L1 immune checkpoint blockade. In this context, Sun et al. carried out a retrospective analysis aimed to evaluate a possible correlation among PD-L1 expression and $\mathrm{CD} 8^{+}$tumorinfiltrating lymphocytes (TILs) density with respect to the outcome of 56 patients with surgically resected SCLC. In the first place, their immunohistochemical study showed PD-L1 overexpression and high CD $8^{+}$TIL density in $39.3 \%$ and $75.0 \%$ of the cases, respectively; that resulted not inter-correlated or correlated with other clinical parameters. In this subset of patients, a prolonged survival was recorded in those expressing high expression of PD-L1 ( $\mathrm{HR}=0.37,95 \% \mathrm{CI}: 0.21-068 ; \mathrm{P}=0.002)$ and those with high $\mathrm{CD}^{+}$TIL density (HR $=0.43,95 \%$ CI: $0.13-0.72 ; \mathrm{P}=0.008$ ). They also presented a statistical model where the patient group with negative PD-L1 expression and low $\mathrm{CD} 8^{+}$TILs density showed the worst outcome ( $\mathrm{HR}=0.36, \mathrm{P}=0.003)$, while the group with high expression of both markers showed the longest survival $(\mathrm{HR}=0.34, \mathrm{P}=0.001)$ (12). In Table 1 are reported the ongoing clinical trials testing immunotherapy

Table 1 Clinical trials testing immunotherapy anti-PD-1/PD-L1/CTLA4 in SCLC (13)

\begin{tabular}{|c|c|c|c|c|}
\hline NCT number & $\begin{array}{l}\text { Study } \\
\text { phase }\end{array}$ & Disease stage & Trial design (experimental arm) & $\begin{array}{l}\text { Est. prim. } \\
\text { compl. date }\end{array}$ \\
\hline NCT03406715 & Phase 2 & $\begin{array}{l}\text { Limited stage (LS) } \\
\text { and extensive } \\
\text { stage (ES) }\end{array}$ & $\begin{array}{l}\text { Combination Immunotherapy With Ipilimumab and Nivolumab Plus a } \\
\text { Dendritic Cell Based p53 Vaccine (Ad.p53-DC) in Patients With Relapsed } \\
\text { Small Cell Lung Cancer (SCLC) }\end{array}$ & April 2020 \\
\hline NCT03670056 & Phase 2 & $\begin{array}{l}\text { Recurrent } \\
\text { extensive stage }\end{array}$ & $\begin{array}{l}\text { A Pilot Study of Combination Immunotherapy With Ipilimumab and } \\
\text { Nivolumab in Patients With Recurrent Extensive Stage Small Cell Lung Cancer } \\
\text { (SCLC) Who Have Previously Received Platinum-based Chemotherapy }\end{array}$ & June 2020 \\
\hline NCT03059667 & Phase 2 & $\begin{array}{l}\text { Limited stage (LS) } \\
\text { and extensive } \\
\text { stage (ES) }\end{array}$ & $\begin{array}{l}\text { Randomized Non-comparative Phase II Study of Anti-PDL1 Atezolizumab } \\
\text { (MPDL3280A) or Chemotherapy as Second-line Therapy in Patients With } \\
\text { Small Cell Lung Cancer }\end{array}$ & $\begin{array}{l}\text { September } \\
10,2018\end{array}$ \\
\hline NCT03223155 & Phase 1 & $\begin{array}{l}\text { Metastatic } \\
\text { (stage IV) }\end{array}$ & $\begin{array}{l}\text { A Randomized Phase I Trial to Evaluate Concurrent Or Sequential } \\
\text { Ipilimumab, Nivolumab, and Stereotactic Body Radiotherapy in Patients } \\
\text { With Stage IV Non-Small Cell Lung Cancer (COSINR Study) }\end{array}$ & $\begin{array}{l}\text { December } \\
2020\end{array}$ \\
\hline
\end{tabular}

Table 1 (continued) 
Table 1 (continued)

\begin{tabular}{|c|c|c|c|c|}
\hline NCT number & $\begin{array}{l}\text { Study } \\
\text { phase }\end{array}$ & Disease stage & Trial design (experimental arm) & $\begin{array}{l}\text { Est. prim. } \\
\text { compl. date }\end{array}$ \\
\hline NCT03983759 & Phase 2 & $\begin{array}{l}\text { Extensive stage } \\
\text { (ES) }\end{array}$ & $\begin{array}{l}\text { Clinical Study of Sequential Sequential Sintilimab Maintenance Therapy in } \\
\text { Patients With Extensive Small Cell Lung Cancer After Chemotherapy } \\
\text { Combined With Adoptive Cellular Immunotherapy }\end{array}$ & $\begin{array}{l}\text { June 20, } \\
2019\end{array}$ \\
\hline NCT03971214 & Phase 1 & $\begin{array}{l}\text { Extensive stage } \\
\text { (ES) }\end{array}$ & $\begin{array}{l}\text { Pilot Study on PD-1 (JS-001) Inhibitors Consolidation After Standard } \\
\text { First-line Chemotherapy and Radiotherapy in Extensive-stage Small Cell } \\
\text { Lung Cancer }\end{array}$ & June 2020 \\
\hline NCT02538666 & Phase 3 & $\begin{array}{l}\text { Extensive stage } \\
\text { (ES) }\end{array}$ & $\begin{array}{l}\text { A Randomized, Multicenter, Double-Blind, Phase } 3 \text { Study of Nivolumab, } \\
\text { Nivolumab in Combination With Ipilimumab, or Placebo as Maintenance } \\
\text { Therapy in Subjects With Extensive-Stage Disease Small Cell Lung Cancer } \\
\text { (ED-SCLC) After Completion of Platinum-based First Line Chemotherapy } \\
\text { (CheckMate 451: CHECKpoint Pathway and nivoluMAb Clinical Trial } \\
\text { Evaluation 451) }\end{array}$ & $\begin{array}{l}\text { October } 1 \\
2018\end{array}$ \\
\hline NCT03585998 & Phase 2 & Limited stage (LS) & $\begin{array}{l}\text { Phase II Trial of Durvalumab (MEDI4736) Maintenance Therapy After } \\
\text { Concurrent Chemoradiation Therapy With Durvalumab (MEDI4736) for } \\
\text { Limited Disease-small Cell Lung Cancer }\end{array}$ & $\begin{array}{l}\text { June 19, } \\
2021\end{array}$ \\
\hline NCT01840579 & Phase 1 & $\begin{array}{l}\text { Extensive stage } \\
\text { (ES) }\end{array}$ & $\begin{array}{l}\text { A Phase I Study of MK-3475 (pembrolizumab) Alone in Subjects With } \\
\text { Advanced Solid Tumors and in Combination With Platinum-Doublet } \\
\text { Chemotherapy or Immunotherapy in Subjects With Advanced Non-Small } \\
\text { Cell Lung Cancer/Extensive-Disease Small Cell Lung }\end{array}$ & $\begin{array}{l}\text { June } 30 \\
2020\end{array}$ \\
\hline NCT04055792 & Phase 2 & $\begin{array}{l}\text { Extensive stage } \\
\text { (ES) }\end{array}$ & $\begin{array}{l}\text { The Efficacy and Safety of Sintilimab Combined With Anlotinib Versus } \\
\text { Anlotinib in Third Line or Beyond Among Patients With Advanced Small } \\
\text { Cell Lung Cancer, a Prospective, Randomized, Controlled, Phase II Clinical } \\
\text { TrialProspective, Randomized, Controlled, Phase II Clinical Trial }\end{array}$ & $\begin{array}{l}\text { March 1, } \\
2021\end{array}$ \\
\hline NCT03262454 & Phase 2 & $\begin{array}{l}\text { Recurrent limited } \\
\text { stage }\end{array}$ & $\begin{array}{l}\text { Sequential Hypofractionated Radiotherapy Followed by Anti-PD-L1 } \\
\text { Atezolizumab for Recurrent or Refractory Small Cell Lung Cancer }\end{array}$ & $\begin{array}{l}\text { December } \\
31,2019\end{array}$ \\
\hline NCT03382561 & Phase 2 & $\begin{array}{l}\text { Extensive stage } \\
\text { (ES) }\end{array}$ & $\begin{array}{l}\text { Randomized Phase II Clinical Trial of Cisplatin/Carboplatin and Etoposide } \\
\text { (CE) Alone or in Combination With Nivolumab as Frontline Therapy for } \\
\text { Extensive Stage Small Cell Lung Cancer (ED-SCLC) }\end{array}$ & June 2, 2020 \\
\hline NCT03554473 & $\begin{array}{l}\text { Phase 1, } \\
\text { phase } 2\end{array}$ & $\begin{array}{l}\text { Relapsed small } \\
\text { cell lung cancers }\end{array}$ & $\begin{array}{l}\text { Safety Run-In and Phase II Trial of M7824 (bifunctional anti PDL1 antibody } \\
\text { and TGF-beta) and Topotecan or Temozolomide in Relapsed Small Cell Lung } \\
\text { Cancers }\end{array}$ & $\begin{array}{l}\text { January 15, } \\
2023\end{array}$ \\
\hline NCT02402920 & Phase 1 & $\begin{array}{l}\text { Limited stage (LS) } \\
\text { and extensive } \\
\text { stage (ES) }\end{array}$ & $\begin{array}{l}\text { Phase I Trial of MK-3475 (Pembrolizumab) and Concurrent Chemo/Radiation } \\
\text { for the Elimination of Small Cell Lung Cancer }\end{array}$ & $\begin{array}{l}\text { July } 31, \\
2023\end{array}$ \\
\hline
\end{tabular}

Table 1 (continued) 
Table 1 (continued)

\begin{tabular}{|c|c|c|c|c|}
\hline NCT number & $\begin{array}{l}\text { Study } \\
\text { phase }\end{array}$ & Disease stage & Trial design (experimental arm) & $\begin{array}{l}\text { Est. prim. } \\
\text { compl. date }\end{array}$ \\
\hline NCT03811002 & $\begin{array}{l}\text { Phase 2, } \\
\text { phase } 3\end{array}$ & Limited stage (LS) & $\begin{array}{l}\text { Limited Stage Small Cell Lung Cancer (LS-SCLC): A Phase II/III Randomized } \\
\text { Study of Chemoradiation Versus Chemoradiation Plus Atezolizumab }\end{array}$ & $\begin{array}{l}\text { December. } \\
28,2026\end{array}$ \\
\hline NCT03166254 & Phase 1 & $\begin{array}{l}\text { Extensive stage } \\
\text { (ES) }\end{array}$ & $\begin{array}{l}\text { Pilot Feasibility Study of the Combination of a Personalized Therapeutic } \\
\text { Anti-tumor Vaccine With Pembrolizumab and Standard of Care } \\
\text { Chemotherapy in Squamous Non-Small Cell Lung Cancer and Extensive } \\
\text { Stage Small Cell Lung Cancer }\end{array}$ & $\begin{array}{l}\text { June } 30, \\
2022\end{array}$ \\
\hline NCT03728361 & Phase 2 & $\begin{array}{l}\text { Limited stage (LS) } \\
\text { and extensive } \\
\text { stage (ES) }\end{array}$ & $\begin{array}{l}\text { A Phase II, Multi-Cohort Trial of Combination Nivolumab and Temozolomide } \\
\text { in Recurrent/Refractory Small-Cell Lung Cancer and Advanced } \\
\text { Neuroendocrine Tumors }\end{array}$ & $\begin{array}{l}\text { December } \\
31,2021\end{array}$ \\
\hline NCT04189094 & Phase 2 & Limited stage & $\begin{array}{l}\text { Chemoradiotherapy With or Without Sintilimab in Limited-stage Small Cell } \\
\text { Lung Cancer: a Multicenter Prospective Randomized Phase II Trial }\end{array}$ & July 1, 2021 \\
\hline NCT04079712 & Phase 2 & $\begin{array}{l}\text { Extensive stage } \\
\text { (ES) }\end{array}$ & $\begin{array}{l}\text { A Phase } 2 \text { Study of XL184 (Cabozantinib) in Combination With Nivolumab } \\
\text { and Ipilimumab for the Treatment of Poorly Differentiated Neuroendocrine } \\
\text { Carcinomas }\end{array}$ & $\begin{array}{l}\text { October 1, } \\
2021\end{array}$ \\
\hline NCT03043599 & $\begin{array}{l}\text { Phase 1, } \\
\text { phase } 2\end{array}$ & $\begin{array}{l}\text { Extensive stage } \\
\text { (ES) }\end{array}$ & $\begin{array}{l}\text { Consolidative Ipilimumab and Nivolumab With Thoracic Radiotherapy After } \\
\text { Platinum Based Chemotherapy for Patients With Extensive-Stage Small Cell } \\
\text { Lung Cancer }\end{array}$ & $\begin{array}{l}\text { October 26, } \\
2018\end{array}$ \\
\hline NCT02554812 & Phase 2 & $\begin{array}{l}\text { Extensive stage } \\
\text { (ES) }\end{array}$ & $\begin{array}{l}\text { A phase } 1 \mathrm{~b} / 2 \text { open-label study to evaluate safety, clinical activity, } \\
\text { pharmacokinetics and pharmacodynamics of avelumab (msb0010718c) in } \\
\text { combination with other cancer immunotherapies in patients with advanced } \\
\text { malignancies }\end{array}$ & $\begin{array}{l}\text { December } \\
16,2022\end{array}$ \\
\hline NCT03841110 & Phase 1 & $\begin{array}{l}\text { Extensive stage } \\
\text { (ES) }\end{array}$ & $\begin{array}{l}\text { FT500 as Monotherapy and in Combination With Immune Checkpoint } \\
\text { Inhibitors in Subjects With Advanced Solid Tumors (Phase 1) }\end{array}$ & March 2022 \\
\hline NCT03761914 & $\begin{array}{l}\text { Phase 1, } \\
\text { phase } 2\end{array}$ & $\begin{array}{l}\text { Extensive stage } \\
\text { (ES) }\end{array}$ & $\begin{array}{l}\text { A Phase } 1 / 2 \text { Study of Galinpepimut-S in Combination With Pembrolizumab } \\
\text { (MK 3475) in Patients With Selected Advanced Cancers }\end{array}$ & $\begin{array}{l}\text { December } \\
31,2020\end{array}$ \\
\hline NCT03228667 & Phase 2 & $\begin{array}{l}\text { Extensive stage } \\
\text { (ES) }\end{array}$ & $\begin{array}{l}\text { QUILT-3.055: A Phase Ilb, Single-Arm, Multicohort, Open-Label Study of } \\
\text { ALT-803 in Combination With PD-1/PD-L1 Checkpoint Inhibitor in Patients } \\
\text { Who Have Disease Progression Following an Initial Response to Treatment } \\
\text { With PD-1/PD-L1 Checkpoint Inhibitor Therapy }\end{array}$ & June 2020 \\
\hline NCT03703297 & Phase 3 & Limited stage (LS) & $\begin{array}{l}\text { Study of Durvalumab + Tremelimumab, Durvalumab, and Placebo in Limited } \\
\text { Stage Small-Cell Lung Cancer in Patients Who Have Not Progressed } \\
\text { Following Concurrent Chemoradiation Therapy (ADRIATIC) }\end{array}$ & $\begin{array}{l}\text { February } \\
2024\end{array}$ \\
\hline
\end{tabular}

NCT NUMBER, National Clinical Trial number; EST. PRIM. COMPL. DATE, Estimated primary completion date. 
anti-PD-1/PD-L1/CTLA4 in patients affected by SCLC (13).

\section{How to increase the efficacy of the immunological treatment}

Anti PD-1 (nivolumab and pembrolizumab) or anti PD-L1 mAbs (atezolizumab, durvalumab, and avelumab) partially enhance the CTLs function and promote a rapid cytolytic effect at the tumor site. However, the antitumor activity of these reactivated cells, rapidly, extinguish not replenished with a fresh supply of tumor-specific immune-effectors (immunopriming) (14). Several studies have shown that the efficacy of effector cells of immune system and crosspresentation of exogenous antigens may be improved by cancer treatment vaccines and other treatments such as radiotherapy, chemotherapy, steroid hormones, and immunologic adjuvant agents (15). In this regard, CTLA4/B7.1 immune checkpoint reduces the proliferation of $T$ cell clones expressing CTLA-4 and triggers the immune suppression activity of Tregs. On this principle, nivolumab combination with ipilimumab a mAbs to CTLA-4, has already shown a promising antitumor activity in SCLC and other malignancies $(6,7)$. Immune priming is spontaneously triggered by cancer cells releasing antigenic material in the lymphatic streams as consequence of cancer-associated inflammation, necrosis, or apoptotic processes. This process may be greatly empowered by tumor cell exposure to either cytotoxic drugs and/or radiation therapy (16). At this purpose, the only immunotherapeutic strategy approved for the treatment of SCLC patients is based on the combination of atezolizumab with platinum-based chemotherapy and etoposide. In fact, we have recently shown that fractioned cisplatin and metronomic oral etoposide (mPE) may trigger significant immunological effects by inducing a Th1 cytotoxic phenotype, decreasing the expression of peripheral Tregs and MSDCs and rising the expression of central memory $\mathrm{T}$ cells $\left(\mathrm{CD}^{+} \mathrm{CD}^{+}\right.$ $\left.\mathrm{CD}^{2} 4 \mathrm{RA}^{-}\right) \mathrm{CCR}^{+}(15,17,18)$. The use of this regimen compared to the standard chemotherapy doublets prior nivolumab administration was associated to a much longer survival in NSCLC (19). Immunotherapy, on the other side, could enhance the efficacy of radiation therapy (RT) directed to primary thoracic disease. The IMpower 133 trial did not permit thoracic RT, although $85 \%$ of patients had lung and/or thoracic node involvement and only $2.5 \%$ of the patients showed complete response. RT, thus, could further improve outcomes in this population as well as enhance the effects of immunotherapy. Radiation therapy, through direct DNA damage, is able to activate significant immunopriming, due to release of antigenic material in a context of immunological danger signaling, which follows the sudden shrinkage of irradiated tumor usually observed in SCLC, that is, triggering radiation-specific immunological effects. This may result also in the s.c. "abscopal effect" (regression of non-irradiated tumor sites) (20). By inducing DNA damage in tumor cells, the radiation can activate the expression of damage-associated molecular biochemical patterns (DAMPs) which in turn may increase tumor antigens presentation to CTL precursors and their proliferation in the draining lymph nodes. Furthermore, inflammatory cytokines, chemokines (such as CXCL16) and tumor vessel associated adhesion molecules (VCAM-I and ICAM-I) released by the irradiated tumor tissue are able to increase the proportion of activated TILs $(20,21)$. Finally, radiation may also upregulate class I HLA molecules, as well as multiple death receptors (e.g., FAS, NKG2DL) in the tumor, thus improving the susceptibility to tumor specific CTLs (20). According with these preclinical results, clinical evidences have been confirmed in the setting of SCLC (22). However, radiotherapy doses, fractionation schedules, volumes, techniques and association schedules with chemotherapy and ICIs must be appropriately tailored in order to avoid overwhelming toxicity. This achievable goal, thanks to the present high-precision technology and accrued experiences, must be tested in suitable clinical studies.

We recently realized a retrospective analysis in advanced NSCLC patients recruited in the BEVA2017 who received an immune modulating treatment with metronomic chemotherapy (mPE) +/- bevacizumab (mPEBev) recording that radiotherapy used in palliative care setting, was connected to a prolonged survival and this result was related to a significant increase in activated DCs and effector memory CTLs induced by the treatment (23). In addition, in a retrospective analysis of the KEYNOTE-001 phase I that investigated the effect of pembrolizumab in a cohort of 495 patients with advanced NSCLC, in 97 patients who had received radiation therapy before immunotherapy a longer PFS and OS have been detected (24). On these bases, a cancer treatment protocol including a rationale use of chemotherapy and radiotherapy could potentially increase the efficacy of immunotherapy. Other clinical trials in the field of immune oncology should consider this examination to ameliorate the benefits of therapies for the outcome of 
SCLC patients.

\section{Acknowledgments}

We wish to thank the ARCO patients' association for their precious fund-raising support to the study.

Funding: None.

\section{Footnote}

Provenance and Peer Review: This article was commissioned by the editorial office, Translational Lung Cancer Research. The article did not undergo external peer review.

Conflicts of Interest: All authors have completed the ICMJE uniform disclosure form (available at http://dx.doi. org/10.21037/tlcr-20-536). The authors have no conflicts of interest to declare.

Ethical Statement: The authors are accountable aspects of the work in ensuring that questions to the accuracy or integrity of any part appropriately investigated and resolved.

Open Access Statement: This is an Open Access article distributed in accordance with the Creative Commons Attribution-NonCommercial-NoDerivs 4.0 International License (CC BY-NC-ND 4.0), which permits the noncommercial replication and distribution of the article with the strict proviso that no changes or edits are made and the original work is properly cited (including links to both the formal publication through the relevant DOI and the license). See: https://creativecommons.org/licenses/by-nc-nd/4.0/.

\section{References}

1. Tsoukalas N, Aravantinou-Fatorou E, Baxevanos $\mathrm{P}$, et al. Advanced small cell lung cancer (SCLC): new challenges and new expectations. Ann Transl Med 2018;6:145.

2. Faivre-Finn C, Snee M, Ashcroft L, et al. Concurrent once-daily versus twice-daily chemoradiotherapy in patients with limited-stage small-cell lung cancer (CONVERT): an open-label, phase 3, randomised, superiority trial. Lancet Oncol 2017;18:1116-25.

3. Pardoll DM. The blockade of immune checkpoints in cancer immunotherapy. Nat Rev Cancer 2012;12:252-64.

4. Rocco D, Della Gravara L, Battiloro C, et al. The role of combination chemo-immunotherapy in advanced non-small cell lung cancer. Expert Rev Anticancer Ther
2019;19:561-8.

5. Hellmann MD, Callahan MK, Awad MM, et al. Tumor Mutational Burden and Efficacy of Nivolumab Monotherapy and in Combination with Ipilimumab in Small-Cell Lung Cancer. Cancer Cell 2019;35:329.

6. Antonia SJ, López-Martin JA, Bendell J, et al. Nivolumab alone and nivolumab plus ipilimumab in recurrent smallcell lung cancer (CheckMate 032): a multicentre, openlabel, phase 1/2 trial. Lancet Oncol 2016;17:883-95.

7. Horn L, Mansfield AS, Szczęsna A, et al. First-Line Atezolizumab plus Chemotherapy in Extensive-Stage Small-Cell Lung Cancer. N Engl J Med 2018;379:2220-9.

8. Khan H, Gucalp R, Shapira I. Evolving Concepts: Immunity in Oncology from Targets to Treatments. J Oncol 2015;2015:847383.

9. Liu CC, Yang H, Zhang R, et al. Tumour-associated antigens and their anti-cancer applications. Eur J Cancer Care (Engl) 2017;26. doi: 10.1111/ecc.12446.

10. Botta C, Misso G, Martino EC, et al. The route to solve the interplay between inflammation, angiogenesis and anticancer immune response. Cell Death Dis 2016;7:e2299.

11. Sitkovsky MV, Lukashev D, Apasov S, et al. Physiological control of immune response and inflammatory tissue damage by hypoxia-inducible factors and adenosine A2A receptors. Annu Rev Immunol 2004;22:657-82.

12. Sun Y, Zhai C, Chen X, et al. Characterization of PDL1 protein expression and CD8(+) tumor-infiltrating lymphocyte density, and their associations with clinical outcome in small-cell lung cancer. Transl Lung Cancer Res 2019;8:748-59.

13. ClinicalTrials.gov. Available online: https://clinicaltrials. gov/ct2/home (Accessed April 02, 2020).

14. Woo SR, Corrales L, Gajewski TF. Innate immune recognition of cancer. Annu Rev Immunol 2015;33:445-74.

15. Nardone V, Pastina P, Giannicola R, et al. How to Increase the Efficacy of Immunotherapy in NSCLC and HNSCC: Role of Radiation Therapy, Chemotherapy, and Other Strategies. Front Immunol 2018;9:2941.

16. Barker CA, Postow MA. Combinations of radiation therapy and immunotherapy for melanoma: a review of clinical outcomes. Int J Radiat Oncol Biol Phys 2014;88:986-97.

17. Martino EC, Misso G, Pastina P, Costantini S, Vanni F, Gandolfo C, Botta C, Capone F, Lombardi A, Pirtoli L, Tassone P, Ulivieri C, Tagliaferri P, Cusi MG, Caraglia M, Correale P. Immune-modulating effects of bevacizumab in metastatic non-small-cell lung cancer patients. Cell Death Discov 2016;2:16025. 
18. Pastina P, Nardone V, Croci S, et al. Anti-cancer activity of dose-fractioned $\mathrm{mPE}+/$ - bevacizumab regimen is paralleled by immune-modulation in advanced squamous NSLC patients. J Thorac Dis 2017;9:3123-31.

19. Giannicola R, D'Arrigo G, Botta C, et al. Early blood rise in auto-antibodies to nuclear and smooth muscle antigens is predictive of prolonged survival and autoimmunity in metastatic-non-small cell lung cancer patients treated with PD-1 immune-check point blockade by nivolumab. Mol Clin Oncol 2019;11:81-90.

20. Demaria $\mathrm{S}, \mathrm{Ng} \mathrm{B}$, Devitt $\mathrm{ML}$, et al. Ionizing radiation inhibition of distant untreated tumors (abscopal effect) is immune mediated. Int J Radiat Oncol Biol Phys 2004;58:862-70.

21. Levy A, Chargari C, Marabelle A, et al. Can

Cite this article as: Correale P, Giannicola R, Saladino RE, Nardone V, Pirtoli L, Tassone P, Luce A, Cappabianca S, Scrima M, Tagliaferri P, Caraglia M. On the way of the new strategies aimed to improve the efficacy of PD-1/PD-L1 immune checkpoint blocking mAbs in small cell lung cancer. Transl Lung Cancer Res 2020;9(5):1712-1719. doi: 10.21037/tlcr20-536 immunostimulatory agents enhance the abscopal effect of radiotherapy? Eur J Cancer 2016;62:36-45.

22. Verma V, Cushman TR, Selek U, et al. Safety of Combined Immunotherapy and Thoracic Radiation Therapy: Analysis of 3 Single-Institutional Phase I/II Trials. Int J Radiat Oncol Biol Phys 2018;101:1141-8.

23. Baird JR, Monjazeb AM, Shah O, et al. Stimulating Innate Immunity to Enhance Radiation Therapy-Induced Tumor Control. Int J Radiat Oncol Biol Phys 2017;99:362-73.

24. Pastina P, Nardone V, Botta C, et al. Radiotherapy prolongs the survival of advanced non-small-cell lung cancer patients undergone to an immune-modulating treatment with dose-fractioned cisplatin and metronomic etoposide and bevacizumab (mPEBev). Oncotarget 2017;8:75904-13. 